\title{
Г.В. Грошева
}

\section{МЕЖДУ «СТАРОЙ» И «НОВОЙ» РОДИНОЙ: ПРЕДСТАВЛЕНИЯ РУССКИХ НЕМЦЕВ В ГЕРМАНИИ}

\author{
Работа написана в рамках научного проекта (№ 8.1.27.2018), выполненного при поддержке \\ Программы повыщения конкурентоспособности ТГУ.
}

\begin{abstract}
Статья посвящена изучению представлений о родине и факторов их формирования у русскоязычных немцев поздних переселенцев (Spätaussiedler), прибывших в Германию из стран бывшего СССР в 1990-е гг. У респондентов исследуемой группы прослеживается тенденция трансформации понятия родина «историческая», одновременно складывается концепция «двух родин». Германия, как «новая Родина», наделяется такими характеристиками, как социально-экономическая стабильность, правовые гарантии, предсказуемость. «Старая» Родина воспринимается как источник значимых личных смыслов и внутреннего психологического удовлетворения.
\end{abstract}

Ключевые слова: Родина; идентичность; поздние переселенцы; русские немцы; Германия.

Образ Родины является основанием не только коллективной идентичности, но и стержнем самоидентификации человека. Особый интерес вызывают представления о родине людей, оказавшихся вне места своего рождения, переехавших на постоянное место жительства в другую страну. В нашем случае - это русскоязычные немцы, прибывшие в Германию по программе поздних переселенцев (Spätaussiedler) из стран бывшего Советского Союза в 1990-е гг., в период четвертой волны иммиграции. Неизменный рост численности немцев-переселенцев в современной Германии и сохраняющиеся сложности их интеграции в немецкое общество обусловливают необходимость изучения факторов формирования идентичности русскоязычных немцев, оказывающей непосредственное влияние на процессы их социальной адаптации.

Согласно статистике Федерального административного ведомства Германии, с 1990 по 2017 г. из стран СНГ переехало 2127338 переселенцев [1. Р. 5; 2]. В 2017 г. наибольшее число переселенцев приехало из Российской Федерации - 2078 человек, из Казахстана - 1785 , Украины - 510, Кыргызстана - 88, Белоруссии - 76 человек. К примеру, из стран Восточной Европы в этом же году в Германию прибыло 11 человек, в том числе с территории Польши - 7, Румынии - 3, бывшей ЧССР - 1 [3]. За январь-июнь 2018 г. в страну прибыло еще 2716 человек [2] В целом на июнь 2018 г. численность русскоязычных немцев из стран бывшего СССР составила 2391478 человек (1950-2018 гг.).

В российской науке существует множество работ, посвященных различным аспектам изучения вопросов эмиграции русскоязычных немцев-переселенцев в Германию, их интеграции и социальной адаптации, опыта реэмиграции и др. Среди известных исследователей, работающих в этой области, можно назвать М.С. Савоскул, Е.В. Казарцеву, И.В. Лебедеву, М.А. Ефремову,
Ю.В. Иванову-Бучатскую, Е.Ю. Протасову и многих других. Имеются специальные работы по изучению институциональных условий интеграции российских немцев в Германии, деятельности отдельных общественных организаций русскоязычных немцев-переселенцев (Е.В. Бадалова, Л.О. Самсонова) $[4,5]$, интеграции русскоязычной молодежи в немецкое общество (Е.В. Казарцева, В. Стерликов) [6, 7].

Особый интерес в контексте рассматриваемой темы имеют работы, посвященные такой проблематике, как идентичность и трансформация самосознания немцевпереселенцев. Так, например, К. Менг и Е.Ю. Протасова анализируют попытки советских (российских) немцев заново определить свою этническую принадлежность - не только по крови, но и по языку и культуре; описывают как под влиянием прежней исторической памяти и нового переселенческого опыта менялась их самоидентификация (в частности, отраженная в самоназвании) [8]. В.Д. Попков в своих работах осмысляет такие сюжеты, как владение русскоязычными переселенцами (русские немцы, русские евреи, русские) информацией о Германии до миграции, восприятие ими СССР и советской действительности, личная оценка причин переезда, внешние поведенческие модели и самоидентификация. Автор характеризует сети связей русскоязычных иммигрантов в Германии (особенности формирования внутренних границ, кроссгрупповые границы в русскоязычном сообществе, связи со странами исхода) $[9,10]$. На основе исследований делается вывод, что не только русский язык и культура, но и ценности и поведенческие нормы, сформированные в ходе социализации и инкультурации в бывшем Советском Союзе, не исчезли с распадом СССР, а продолжают транслироваться мигрантами из СССР в местах их настоящего проживания. Ю.В. Иванова-Бучатская описывает, как проявляет себя идентичность пересе- 
ленцев в культуре оформления жилого пространства [11]. В работах перечисленных выше авторов поднимается и проблема трансформации образа Родины в сознании немцев-переселенцев, и влияние этого процесса на формирование их идентичности и интеграцию в немецкое общество, однако эта тема до сих пор не стала предметом специального изучения.

Цель статьи - выявить характер представлений о Родине в среде русскоязычных немцев-переселенцев из стран бывшего Советского Союза и факторы их формирования. В нашем случае это представители этнически смешанных русско-немецких семей, переехавшие в основном из России, а также из Казахстана и Кыргызстана. В общественном дискурсе Германии, эта категория иммигрантов, несмотря на страну исхода, именуется «российскими» или «русскими» немцами. Термин «русские немцы» также является одной из форм самоназвания поздних переселенцев, определяющими характеристиками самосознания которых часто являются не этничность и гражданство, а язык («русскоязычность») и культурные практики [8. С. 16-18; 9. С. 144 145]. Использование этого термина в статье также обусловлено спецификой эмпирической базы исследования - обращением к анализу материалов интервью с респондентами, состоящими в этнически смешанных русско-немецких браках или рожденными в смешанных браках (имеющими русско-немецкое этническое происхождение).

Поднимаемая в работе проблематика требует осмысления в рамках методологии транснационализма, согласно которому оказывается возможным отказ от анализа феномена миграции через призму национального государства, а мигранты могут рассматриваться как обладатели двух и более идентичностей, включенные в социокультурную среду, экономическую и, часто, политическую жизнь как принимающих государств, так и стран исхода $[12,13]$. В отношении русскоязычных немцев-переселенцев этот подход активно применяют в своих работах М.С. Савоскул и В.Д. Попкова. М.С. Савоскул дает характеристику основных типов трансграничных связей российских немцев, выявляет факторы, определяющие типы и интенсивность этих связей, оценивает их вклад в развитие региона выхода, описывает внутренние сети взаимодействия немцев-переселенцев [14-16]. В.Д. Попков анализирует созданное русскоязычными мигрантами трансгосударственное / транснациональное русскоязычное пространство, пишет о выстраивании ими между страной поселения и странами исхода связей высокой интенсивности и частоты [9].

В исследовании используется микроисторический подход, в центре внимания которого находятся, прежде всего, конкретный человек, его внутренний мир и социальные практики. Выбор микромасштаба дает возможность взглянуть на происходящие процессы с позиции их участников [17. С. 92], реконструировать жизненные стратегии, видимые «только с очень близ- кого расстояния» [18. С. 17], увидеть, как в судьбу «маленького человека» вписалась большая история [19. C. 8]. При анализе материалов интервью, составивших источниковую базу работы, в качестве вспомогательного применялся метод лингвистического дискурсанализа, суть которого состоит в интерпретации различного рода текстов или высказываний как продуктов речевой коммуникации людей, осуществляемой в конкретных культурно-исторических условиях [20]. Это позволило выявить основные характеристики образа Родины и проследить реализацию установок в отношении данного концепта, проявляющихся на вербальном уровне.

Работа основана на эмпирическом материале, собранном в 2014 г. в Филлинген-Швеннингене (федеральная земля Баден-Вюртемберг, ФРГ). Методы исследования включали полуструктурированные глубинные групповые и индивидуальные интервью, а также включенное наблюдение. Во время интервью затрагивались такие темы, как история переезда в Германию, преимущества и сложности жизни в Германии, особенности взаимоотношений между российскими немцами и немцами Германии, проблемы самоидентификации переселенцев и их интеграции в немецкое общество и др. Тема Родины в интервью не задавалась специально, обращение к ней происходило естественным образом в ходе рассуждений. Тем не менее материалы интервью составили полноценную источниковую базу для изучения обозначенной темы, дают комплексное представление о формировании образа Родины в сознании исследуемой группы русских немцев.

Интервью проводились на русском языке, в виде свободной беседы, и записывались на диктофон с согласия собеседников на условиях сохранения конфиденциальности, поэтому при цитировании материалов в статье используется шифрование с указанием пола, возраста и места рождения респондентов. В фокусе исследовательского интереса оказались три молодые супружеские пары, каждый из супругов в которых родился в этнически смешанной русско-немецкой семье (активное участие в интервью принимали 5 человек). Молодые респонденты переехали в Германию с родителями в 1995-1997 гг. в возрасте 8-14 лет, создали там семьи и на момент интервью уже имели собственных детей. Все респонденты этой группы успешно освоили немецкий язык, получили высшее - Hochbildung (3 муж. и 1 жен., родились в России) и среднее специальное - Ausbildung (2 жен., место рождения - Казахстан и Киргизия) образование и работают по специальности. В поле внимания оказались и представители старшего поколения - две супружеские пары в возрасте 58-65 лет, являющиеся родителями части из указанных выше респондентов (активных собеседника - 3 человека). Это явилось важным моментом, позволяющим обратиться к вопросу о роли семьи в социокультурной адаптации и формировании идентичности представителей молодого поколения мигрантов. Три респондента 
старшего поколения (1 муж. и 2 жен.) имеют высшее образование, у одного - среднее специальное. Каждому из них удалось найти постоянное место работы в Германии, но лишь один трудоустроился по специальности (1 муж., высшее образование). Переезд для этой группы респондентов, за исключением одного случая, сопровождался снижением социального статуса. Три респондента (2 муж. и 1 жен.) из этой группы родились в России, один (жен.) - в Казахстане. На момент переезда в Германию обе супружеские пары проживали в России. Всего в центре внимания, учитывая метод включенного наблюдения, оказались 15 человек (представители трех поколений: молодые супружеские пары, их дети и родители).

Указанным респондентам, с целью углубления изучения их представлений о Родине и выявления динамики этих представлений, в 2018 г. было предложено дистанционно принять участие в полуструктурированном анкетировании. В содержание гайда были включены такие вопросы, как «Что такое Родина?», «Где сейчас Ваша родина?», «Что Вам приходит на ум, когда Вы слышите об СССР? О России?», «Что сейчас чаще всего вспоминается о жизни в СССР? В России?». Формулировка вопросов была заимствована из составленного В.Д. Попковым «Путеводителя тематически-центрированного интервью» (Тема 5. Идентичность) [9. С. 462-463] с целью сопоставления результатов исследований автора путеводителя и автора настоящей статьи. Замысел реализовать не удалось, поскольку на предложение об участии в анкетировании откликнулось всего 2 человека. Использование же материалов анкетирования в статье позволило проследить динамику изменений в установках респондентов на индивидуальном уровне и зависимость этих установок от внутренних и внешних факторов.

Эмпирическая база исследования позволяет систематизировать материал в соответствии со следующими выделенными сюжетами: причины переезда в Германию и рассуждения о потере «старой» Родины, образ Родины в контексте ностальгии по СССР и стране исхода, проблема идентичности и роль представлений о Родине в ее формировании, понятие Родины в контексте проблем интеграции и социальной адаптации, отношение респондентов к современным России и Германии.

Причины переезда в Германию и рассуждения о nотере «старой» Родины. В 1990-е гг., на которые приходится переселение участников опроса в Германию, страны СНГ переживали тяжелые времена. Следствием распада СССР стали экономическая разруха, неустойчивая политическая ситуация, угроза разрастания военных конфликтов и др. Отсутствие видимых перспектив улучшения ситуации побуждали русскоязычных немцев к выезду из стран постсоветского пространства. Для немцев-переселенцев из республик СССР - это и начавшиеся в конце 1980-х - начале 1990-х гг. процессы дискриминации по этническому признаку, приводившие к их частичной языковой и социальной изоляции (как русскоязычного населения) и побуждавшие к выезду в Германию. Многими немцами двигало желание вернуться на свою историческую родину. Начало массовой эмиграции немцев из республик бывшего СССР было положено принятием в 1986 г. указа М. Горбачева «О въезде и выезде из СССР», однако пик переселения приходится на период 1991-1995 гг., когда на постоянное место жительства в Германию уехали 825546 этнических немцев [21. С. 156]. Переезд в Германию поздними переселенцами связывался с наличием более широких перспектив собственной реализации и лучшего будущего для своих детей. Переселенцами двигало желание стать частью общества с более высоким жизненным стандартом с определенными социальными гарантиями и стабильной правовой системой.

Все участники интервью, вне зависимости от возраста и этнического происхождения (немецкого, русского, смешанного немецко-русского), отметили, что основной причиной эмиграции из стран постсоветского пространства для них было не возвращение на историческую родину, а болезненная экономическая трансформация и ухудшение социально-политической ситуации в стране исхода вследствие развала СССР, тревога за будущее своих детей.

«Если бы не развал Советского Союза, не было бы такого массового переселения. Было бы как в 70-х годах уезжали... Поехали не потому, что остро затосковали, не потому, что хотят на свою родину, в Германию. <...> А потому, что там развалили то, где мы родились, к чему привыкли. <...> И вот просто от того, что начался хаос, по-другому и не сказать, многие семьи спасали своих детей от того беспредела, чтобы они не стали там наркоманами, еще кем-то. <...> И поехали в ту страну, где было благоприятней для своей семьи. Все. Элементарно, вот чувство выљсивания людьми тогда двигало» (Ж., 58 лет. Казахстан) ${ }^{1}$. В 2018 г. эта же респондентка пишет о Советском Союзе следующее: «Вот где Родина, ее нас лишили без нашего ведома, вот и побрели полстраны по свету, чтобы детей сберечь...». Рассказы женщины наполнены эмоциональными моментами, она повествует не об обычных финансовых трудностях, с которыми столкнулась ее семья - для их семьи это был вопрос «спасения» и «выживания». В цитируемых рассуждениях отчетливо звучит мотив лишения родины: разрушение СССР указывается как внешняя причина ее потери.

Один из участников интервью, респондентмужчина, отметил в качестве причины переезда страх возможного привлечения государством его сыновей к участию в военных действиях в Северо-Кавказском регионе: «Элементарно от войн, агрессора... Чечня» (М., 60 лет. Россия). Необходимо отметить, что его семья эмигрировала из России в 1995 г., в период Первой чеченской войны (1994-1996 гг.), дети были еще школьного возраста. Однако призывной возраст парней 
пришелся бы на время Второй чеченской кампании (1999-2009).

Респонденты из числа молодежи в качестве причин переезда в Германию также отмечают социальноэкономическую нестабильность и желание старших родственников обеспечить им благополучное будущее.

"Вообще мы из Сибири ехали сюда, скажем, на такой волне - все ехали. Все “за бугор” смотрели. <..> Если бы вот переместиться во времени, то мы бы вряд ли куда-то поехали. Просто тогда было очень сложно, поэтому уехали» (М., 32 года. Россия).

«Mы приехали из Казахстана. <...> В 97-м году. $<\ldots>$ Там развал, разруха, ужасно было. Света не было там, я не знаю, неделями. Понятное дело, что нужно было собираться. Мама моя, конечно, против была. Не совсем хотела, потому что у нее там мама осталась и брат. <..> Но моя бабушка сказала: "Езжайте!", потому что ради детей, да» (Ж., 34 года. Казахстан).

При этом респонденты продемонстрировали понимание, что цели отъезда российских немцев разных волн миграции различаются, что есть и те, кто уезжал в Германию, прежде всего, руководствуясь желанием вернуться на свою историческую родину. При этом отмечается немногочисленность таких эмигрантов и их принадлежность к переселенческой волне 1970-х гг. «И потом ещзе, переселениьь - это слово одно, а оно же тоже очень многослойное. Если, допустим переселенизь 70-х годов - это одни переселенцы, 80-х - другие, 90-х - это вообще третьи. <...> Скажем, в 70-х годах, которые приехали, они интегрировались. <..> Это ехали те люди, которые, действительно, хотели на свою историческую родину. Им так внуиили родители, что если будет возможность, то уезжайте в Германию - это наша Родина» (Ж., 58 лет. Казахстан). Представители молодого поколения отмечают, что установки молодежи в подобных случаях во многом зависят от позиции их родителей, их отношения к стране исхода и принимающей стране: «Hy, во-первых, я думаю, многое от родителей идет. Я думаю, большая часть, наверное $<\ldots>$ Нас там ни за кого не считали <... Э Это наша родина, мы сюда приехали. Вот наша родина. Там мы вообще никто были <...> Мне кажется это детям, как-то накручивая, говорят» (Ж., 34 года. Казахстан).

Интересно встретившееся в среде респондентов старшего поколения переживание о том, что, переехав в Германию, они лишили своих детей родины. «Но вот у меня, например, неприятное чувство внутри есть, то, что мы у детей отобрали Родину. У них практически сейчас нет ни здесь родины, ни в России. Они как бы между двумя странами, где одной родины, ну, с великим патриотизмом, что ли, нету. Потому что мы их, как бы, разорвали. Мы дали им ещче часть какой-то родиньл. Пусть по матери, потому что мама - немка в поколениях. А вот чувства такой Родины, действительно, отобрали. Потому что они туда приезжают - они там не совсем свои, и здесь не совсем свои. И вот чувство Родины, я думаю, такое сомнительное у многих русских переселенцев» (М., 60 лет. Россия). Вновь звучит мотив лишения родины, однако в данном случае речь идет не о внешних причинах, а о чувстве собственной вины перед молодым поколением за то, что они «отобрали» у них родину - Родину с «с великим патриотизмом».

В рассуждениях респондентов отчетливо выражены «внешние» факторы эмиграции немцев вследствие распада СССР («развалили, «лишили»), ключевыми среди которых названы экономическая разруха, хаос, беспредел, угроза жизни. В отношении стран исхода респонденты не выразили негативных эмоций, не упоминали фактов дискриминации в свой адрес по этническому принципу, некоторые из респондентов отметили, что не уехали бы при других обстоятельствах. Для большинства эмиграция не воспринималась как возвращение на историческую родину; немецкое происхождение одного из членов этнически смешанных семей было основанием для переезда в Германию, с которой связывались надежды на благополучное будущее. В среде старшего поколения присутствует чувство вины перед детьми, оставленными без Родины («отобрали», «разорвали») / с «сомнительным» чувством Родины / «между двумя странами».

Образ Родины в контексте ностальгии по СССР и стране исхода. Достаточно интересным оказывается обращение респондентов и старшего, и молодого поколений к сюжету о ностальгии по отношению к СССР и стране исхода. Кто-то из интервьюируемых очень кратко, не разворачивая тезиса, отметил: «Ностальгия по тем временам» (М., 60 лет. Россия), кто-то уделил этому сюжету особое внимание. Респондентка старшего поколения из числа этнических немцев, родившаяся и жившая до 17 лет в Казахстане, затем уехавшая в Сибирь для продолжения учебы и впоследствии переехавшая туда на постоянное место жительства, на вопрос о каком месте она больше скучает о Казахстане или России, ответила: «Нет, по Советскому Союзу, вот это вот была страна - интернациональная. И вот когда нынче в Туричи мы встретили казахов - это наши казахи, это не турки, не арабы, которые скажем для нас люди другой наџиональности, а казахи - они наши. Вот украинџы со свочми веночками на голове это наши, чеченцы со свочми чеченскими танцами это наши, грузины со своими грузинскими танцами и со своим разноголосьем - это наши. И никак... не можем мы вот с эти согласиться, что все это “не наше” теперь, скажем. Мы все были как бы братья» (Ж., 58 лет. Казахстан).

Такая позиция встретилась и среди собеседников из числа молодого поколения респондентов. «Да, ностальгия немножко есть. Мне кажется, у нас ностальгия по Советскому Союзу, больше чем у тех, кто живет в России. Потому что мы приехали из того времени, и у нас остановилось это. До сих пор мы живем головой в 90-х годах, где-то. <...> В 80-х, да», «Ну как-то передается, мне кажется через родителей. Все 
равно, какие-то воспоминания, которые... даже вот мы иногда смотрим видео... мы там жили. Все равно приятные ощущения» (Ж., 31 год. Россия). Вновь отмечается роль родителей в передаче установок в отношении «старой» Родины и формировании ее образа. Стоит отметить, что отец цитируемой респондентки (русский по этническому происхождению) привез из России и сохранил ее школьную форму, пионерский галстук, прописи, тетради по различным предметам. Однако наиболее персонифицированными и эмоциональными оказались воспоминания собеседницы о родном сибирском городе, в котором она провела свое детство, о покинутых друзьях: «И что помню из России. Детство немножко вспоминаю. И помню, что когда мы уезжали, было очень сложно. И не то, что мы покидали Россию, а просто покидали друзей. <..> Россия, да. Приятно, хорошо. Но вот больше к людям, все равно, тянет», "Да, мы с папой я помню... Каждый раз я его затаскивала в кафе “Золотой ключик” в Томске. И первым делом, когда я приезжаю в Томск, я... Обязательно идем в это кафе и не знаю, по 10 мороженое там съедаю, потому, что хочется именно вот этот знакомый вкус с детства».

Интересно замечание цитируемой выше представительницы старшего поколения, в котором она весьма рационально объясняет, почему кто-то испытывает ностальгию больше, кто-то меньше, а кто-то и вовсе ее не испытывает. «Есть много людей, которые приехали из разных мест, русскоязычные. И в Казахстане, допустим, до одного из областных иеентров или до города 400 км, до другого 200 без всяких дорог - это такая деревня, где не было ни света, ни воды - ну что о ней вспоминать, скажем. Или, допустим, люди приехали из Томска, или люди приехали из Питера, или из Москвы это ж совершенно другие люди. Или те, кто приехал с Краснодарского края, где рай - в том смысле, что в саду все само растет. <...> И скучать кому-то есть по России, а кому-то не почему. Или, допустим, из Киргизии и Казахстана многие семьи выехали прямо вместе, деревнями. Прямо были немецкие деревни и все, не осталось никого. Прямо братья, сестры, все соседи, все здесь. И еще, небольшое такое вот наблюдение. Ностальгия больше у тех людей, которые приехали из России. Не из республик, а из России» (Ж., 58 лет. Казахстан).

В этих рассуждениях присутствует понимание того, что чувство ностальгии (ее наличие или отсутствие) зависит от отношения к малой родине, конкретному месту проживания, сохранения или потери личных связей с прежним местом жительства («выехали прямо вместе», «не осталось никого»). Тезис о том, что ностальгия больше проявляется у тех, кто эмигрировал из России, а не из других стран СНГ, может также служить косвенным свидетельством сожаления об утрате Родины как единого русскоязычного культурного пространства.

Приведенные выше высказывания респондентов являются яркой демонстрацией того, что ностальгия у русских немцев проявляется скорее не по стране проживания, а по конкретному месту, малой родине («кафе “Золотой ключик” в Томске», «...Краснодарского края, где рай»), по времени («по тем временам», «приехали из того времени», «живем головой в 90-х годах. <..> В 80-х», «знакомый вкус с детства»), людям («покидали друзей», «больше к людям... тянет»), по определенному культурно-цивилизационному пространству («была страна - интернациональная», «все были как бы братья»). Основной мотив этих рассуждений - это рассказ о «потере старой Родины», потере СССР, воплощающего в себе образ идеальной Родины - единой, сильной, многонациональной, образ транслируемый старшим поколением - младшему.

Проблема идентичности и роль представлений о Родине в ее формировании. Анализ материалов интервью показывает, что для большинства респондентов из исследуемой группы, уже долгие годы проживающих в Германии, вопрос самодентификации продолжает оставаться актуальным. В ходе бесед они определяли себя как «немцы», «российские немцы», «русские немцы», «русские», «наполовину русские, наполовину немцы» и др. Только для информантов-мужчин старшего поколения (этнических русских) свойственна четкая идентификация себя как «русских». Для молодежи в большей степени характерна двойная руссконемецкая идентичность; у представителей мужского пола - с ярко выраженным превалированием русской. Переселенцы и первого, и второго поколения живут с осознанием принадлежности к двум мирам, двум культурам. Однако в размышлениях о Родине их позиции не столь одинаковы.

«A вот насчет того, какие мы, как мы себя идентифицируем. То есть мы русские или немиьь? Вот у меня вот такое представление. Вот так вот глобус. Вот здесь Россия и здесь Германия. И одна богатая, $и$ культурная, и развитая страна, и другая богатая традициями. Я допустим вот чистая немка, я всегда... Ну, и я люблю очень сильно русский народ. Ну, вот это просто, когда любишь кого-то, ни за что, а вопреки, скажем. Ну, вот просто люблю русских. И я так счастлива, что у меня дети наполовину русские, наполовину немиь, как будто мы одной рукой держим Германию и Россию другой рукой. Mы как бы являемся посредниками» (Ж., 58 лет. Казахстан).

Для цитируемой респондентки характерны и рассуждения космополитического характера: «И вообще, честно сказать, нет у людей родины, есть одна Земля. И только тут я поняла, что мы все одинаковые. <..> Мы вот, турки тут вот работают, или итальянцы, или греки, или русские, или немиы - мы все в одной лодке. Все. Ине важно, на каком языке мы разговариваем».

Эта же респондентка в 2018 г. в анкете на вопрос «Где сейчас ваши Родина?» ответила: «Моя Родина СССР. Для всех людей моего поколения из всех республик (в Москве я разговаривала с таксистом - грузином, проживающим в Москве 30 лет), Родина - СССР. Или 
для большинства. РАВЕНСТВО, БРАТСТВО, ДРУЖБА. А сейчас особенно ценим это бедное, но дружное проилое... Спустя годы, понимаешь: лучше шоколад в газетной обертке, чем <..> Там жила душа. Здесь все блага для тела». Можно предположить, что такая эволюция суждений связана с процессами трансформации идентичности немцев-переселенцев в новых социокультурных условиях после переезда в Германию и с осмыслением современных меняющихся социальных и политических реалий.

Пример рассуждений о родине переселенца старшего поколения (этнического русского) наглядно демонстрирует соотнесение Германии как «места проживания» с комфортом, достатком и уверенностью в будущем: «Живу я здесь, а душа моя - там. Здесь комфортнее, спокойнее. Я за детей спокоен, за их будущеее. Я очень мечтал, чтобы они образованными стали. Ну, как минимум, чтобы институт закончили. Это исполнилось. Я доволен. Организовали семьи, появились внуки. Все очень хорочо. Жить здесь можно. Но както слишком спокойно, что ли... Как на кладбище. (Смеется. - Примеч. авт.). Все как на озере, вода так потихонечку течет» (М., 60 лет. Россия). В Германии - спокойствие, удовлетворенность и предсказуемость, граничащие со скукой, а «душа» респондента «там», в России. Понятие родины для русских по этническому происхождению респондентов старшего поколения однозначно соотносится с Россией.

Высказывания молодых переселенцев разнятся: «две родины», «родина больше в России», «родина - в России». Первые две позиции доминируют в их сознании и предполагают наличие «двух» родин. Пример этой группы респондентов, относящихся к одной социальной нише, свидетельствует о том, что разница в установках не всегда определяется уровнем владения немецким языком и степенью интеграции в немецкое общество.

«Я говорю: “У меня две Родины!” Мне Россия дала очень многое. $<\ldots>$ А здесь мне Германия дала и образование, и спортом мы здесь стали заниматься. Здесь и жена у меня, и ребенок. Все получается здесь. <..> Все равно ближе... Я до сих пор чувствую, что я из России, мои корни в России. И на русском я разговариваю» (М., 33 года. Россия).

«Ну, у меня супруга, она тоже можно сказать, из бывшего Советского Союза, из Киргизии. <...> Для меня всегда было важно - русская девушка, потому что менталитет такой же и культура. Все-таки, хоть я и приехал в 11 лет сюда, все равно мне ближе русская культура, менталитет»; «B 11 лет приехал, сейчас 30 лет. Прожил больше, но все равно, как бы, видимо осталось то, что было заложено в России. Все-таки, Родина больше там, конечно» (М., 30 лет. Россия).

У русскоязычных немцев-переселенцев формируется осознание своей отличительности и от коренных немцев, и от русских страны исхода. В размышлениях об идентичности переселенцев второго поколения можно обнаружить одновременно и декларируемое чувство принадлежности немецкой и русской культурам, и некий маргинальный статус пребывания вне этих культур. «Это сосуд, в который все слили, и там это все размешалось. Вроде как, и не там, и не здесь. Вроде как, географически над Польшей зависли. И все, и не понятно где. И, вроде, не немџы, и уже не русские. Ну, мне так кажется, я так себя чувствую. Если разговаривать с русскими, с настоящими русскими в России - это другие люди, на самом деле. Все равно они по-другому мыслят, и они реагируют на слова по-другому» (М., 32 года. Россия). Отсюда у собеседника и сложный комплекс чувств в размышлениях о родине: «Чувство Родины мне, кажется, есть, но оно, может быть, искаженное. Кажется, что родина, все-таки, в России. <... А ты думаешь, надеешься и желаешь самого доброго России, Родине, в принципе, по сути. То есть, патриотизм-то существует. <..> То есть, получается, что чувство Родины есть и патриотизм, но это где-то там, а ято здесь. Поэтому нельзя все-таки категорично сказать, что Родина и Россия - вот этим я живу. Сложно, это очень сложно». Однако в 2018 г. этот же респондент на вопрос «Где сейчас Ваша Родина?» дал уже краткий и однозначный ответ: «Моя родина - Россия».

Респонденты из числа второго поколения иммигрантов стараются приобщить своих детей, родившихся в Германии, к русскому языку и русской культуре. В молодых семьях разговаривают на русском языке, воспитывают детей на русских сказках, учат их читать и писать по-русски. Ответы респондентов на вопрос «Почему Вы придаете большое значение обучению детей русскому языку?» свидетельствуют о желании сохранения психологически комфортной среды общения в семье и стремлении сохранить память об исторической родине.

«Если наши дети не будут разговаривать на русском, то их дети, может уже и знать не будут, что кто-то там когда-то приехал из России. <...> Поэтому и детям это надо дать, чтобы они несли это, не стеснялись этого» (Ж., 34 года. Казахстан);

«Мне кажется нельзя забывать корни. Все равно нам очень важно, чтобы наш ребенок разговаривал порусски. И знал где-то и корни, и историю своей страны, России. Потому что как-никак все равно мы оттуда» (Ж., 31 год. Россия);

«Внучка тоже говорит на русском (возраст девочки 4 года. - Примеч. авт.) <...> На русском языке с ней говорить интереснее. С ней можно общаться, разговаривать; она знает очень много слов. <..> Песни слушает на русском. Гимн российский почти наизусть знает» (Ж., 59 лет. Россия).

Молодежь воспроизводит модель поведения своих родителей, не давших им забыть русский язык и культуру, что является ярким примером вертикальной культурной трансмиссии - передачи культурных ценностей, убеждений, умений и мотивации от родителей к детям [24. C. 391]. 
Немаловажным для сохранения русской составляющей идентичности и ментальной связи с покинутой родиной стало и то, что при переезде в Германию респонденты решили сохранить себе и детям русские имена и фамилии. При получении новых документов у них, как представителей смешанных немецко-русских семей, на основании Закона о перемещенных лицах и беженцах (§ 94) [25] была возможность сменить имена и фамилии на немецкие. Также, воспользовавшись возможностями немецкого законодательства (Закона о гражданстве (§ 7) [26] и Закона о перемещенных лицах и беженцах (§ 15, п. 1 и п. 2) [27]), они сохранили себе и детям российское гражданство.

Результаты исследования свидетельствуют о взаимной обусловленности проблемы самоидентификации русских немцев и формированием их представлений о родине. Смешанная русско-немецкая идентичность, характерная для большинства респондентов независимо от их возраста, способствует формированию концепции «двух родин» в сознании переселенцев. При этом происходит трансформация представлений об «исторической родине». Можно предположить, что до переезда для большинства респондентов (этнических немцев и их детей из смешанных браков) в качестве исторической Родины воспринималась Германия, то после эмиграции таковыми выступают СССР и Россия как «центр» русского мира. В тесной связке с рассуждениями о Германии используются такие характеристики, как «богатая», «культурная», «развитая», «блага для тела», «комфортнее», «спокойнее»; о России «Родина», «историческая родина», «корни» «богатая традициями», «русский язык», «русская культура», «менталитет», «душа», «патриотизм». Для всех респондентов характерно стремление передать русский язык и культуру детям. В размышлениях русских немцев встречается позиция, свидетельствующая об осознании себя «посредниками» между Германией и Россией. Соотнесение понятия «Родина» с Советским Союзом является временно́й проекцией самосознания («равенство, братство, дружба», «там жила душа», «бедное, но дружное прошлое»).

Понятие Родины в контексте проблем интеграции и социальной адаптации. Как следует из проведенных интервью, при видимой успешной социальной интеграции наших респондентов в немецкое общество, их психологическая интеграция является процессом незавершенным. «Вот я бы об этой иллюзии и говорил, люди думают, что они в Германию приехали $-\kappa$ себе домой. А потом оказывается, что, все-таки, не совсем домой. < ..> Потому, что у меня кровь немецкая, это не значит, что я-немец. Если себя не ощущаю немцем. Ну как это. Как тебе навязать, что ты немеи? Невозможно» (М., 32 года. Россия).

Своеобразной компенсацией потери прежней родины и невозможности полноценного укоренения на новом месте становится формирование таких внутренних структур переселенческого сообщества, как русские магазины, рестораны, дискотеки, русскоязычные СМИ и интернет-сайты и др.
«Почему у наших русских здесь, или наших переселенцев, у всех стоят телевизоры с российским телевидением, почему? Музыка играет русская. В ресторанах гулять - тоже только в русских <... К Какой-то создан микромир для русских. И создали же мы сами его. Потому что, как бы, быть более-менее приближенньми к России, ну или к своей Родине - Советскому Союзу, потому, что многие приехали из Казахстана, из Киргизии. <..> И все равно все, как мне кажется, чисто мысленно туда тянутся»; «Все равно живут в таких, как бы своих мирах, маленько так отдаленных от Германии. Нельзя сказать, что прямо вот в Германии, интегрировались в Германии и все. <..> обзавелись только немецкими друзьями, забыли полностью Россию. Я не могу так сказать о своих сверстниках» (М., 32 года. Россия).

«<..> мне кажется, когда-то мы все приехали из России. Все равно, мы оттуда приехали в другую, чужую страну, и охота создать что-то похожее, хотя бы немножко на то, откуда ты приехал. <... Есть такой момент. Села за стол и ешь пельмени. Ну и тебе хочется, тебе приятно, что ты сидишь. И все знают это. И общзаешься» (Ж., 31 год. Россия).

«Частицей» родины в Германии, символом принадлежности к «русскому миру» становится и православная церковь: «Ну, во-первых, я сама крещееная в православной церкви. Крестили в советское время, и, живя там, я ходила в русскую ичерковь. <..> Естественно, это как-то все ближе. Для меня эти все католические иеркви это все не мое. Я понимаю, я захожу туда, я не чувствую себя там хорошо. Для меня все это очень холодно. Не родное. А это так же кусочек твоего родного чего-то. Так же русская церковь, все эти обычаи, все традиции. Это все твое родное. И ты когда заходишь, у тебя («Ах!») вся душа нараспашку. Все, вплоть до мурашек..., когда ты стоишь, слушаешь пение или, там, на иконь смотришь. Ну не знаю, это частичка Родины так же осталась» (Ж., 34 года. Казахстан). Дети в двух опрошенных молодых супружеских парах были крещены в православной церкви.

В контексте рассуждений о тяге к русским корням интересны наблюдения самих респондентов о том, что даже более молодые переселенцы (по определению интервьюируемых, «двадцатилетние», «следующая генерация»), полностью интегрировавшиеся в немецкое общество и практически не говорящие на русском языке, посещают русские клубы, русские дискотеки и пр.

«<..> в кавычках, это русская дискотека, то есть там музыка русская играет, и, вроде как, они идут на “русскую дискотеку”, потому что они себя считают русскими, где-то. Но говорят они на немецком, вот. Какой-то абсурд получается. Ну, что значит “абсурд”... Они просто и не знают русского языка, потому что и родители их говорить разучились» (Ж., 31 год. Россия).

Разрыв переселенцев с родиной компенсируется и сохранением тесных связей с родственниками и друзь- 
ями в России и других странах СНГ, чему способствует развитие сферы современных коммуникаций и сохраняющиеся возможности достаточно свободного пересечения государственных границ.

«Я приехал в Германию в 95 году. Мне тогда было 14 лет. На сегоднямний день мне 33 года. Уже 19 лет в Германии. <..> Ну, связывает нас с Россией, с русскими очень многое. До сих пор общаемся с друзьями, и хорошо, что есть интернет. <...> Сначала письмами можно было переписываться. У меня стопка огромная вот этих писем с друзьями. <..> Сейчас интернет, сейчас намного легче. Можно перезваниваться и, даже друзья в гости приезжали. И я ездил тоже. <...> Ну вот сколько, за 19 лет, я не знаю, раз восемь, может быть. Восемь, семь... Каждый второй, третий год» (М., 34 года. Россия).

«Ну, последний раз я был три года назад. И до этого тоже три года. А так, до тех пор, пока не женился, я там был, скажем, в среднем каждые два года. Вот» (М., 30 лет. Россия).

«Вот за 19 лет я в России был раз 14. <..> Mbl с семьей сколько раз ездили. Как минимум раз шесть» (М., 60 лет. Россия).

Материалы исследования позволяют проследить взаимосвязь проблем интеграции и социальной адаптации поздних переселенцев с осознанием понятия «Родина», чувств и эмоций по отношению к ней. Свидетельством неполной психологической интеграции на «новой» Родине является использование по отношению к ней следующих характеристик: «не совсем домой», «в другую, чужую страну», «очень холодно», «не родное». Создание переселенческих внутренних структур трактуется участниками бесед как стремление воссоздать близкую к родине микросреду, вписать образ «старой» Родины в жизненные реалии «новой» («микромир для русских», «частичка Родины», «кусочек твоего родного»). При обсуждении проблем интеграции респонденты продемонстрировали важность сохранения русской культуры и развитие связей с Россией. Развитие сети интернет и частые поездки в Россию позволяют сохранять тесные связи с покинутой Родиной и актуализировать представления о ней.

Отночение респондентов к современным России и Германии. Все респонденты в ходе интервью выразили самые добрые чувства в отношении России; отметили, что в России им нравится, они любят Россию, испытывают чувство патриотизма. Свой опыт проживания в Германии они также оценивают позитивно: выражают признательность своей новой родине, удовлетворены полученным образованием, местом работы, разворачивающимися перед ними перспективами. Характеристики в отношении государств респондентами, как правило, давались в сравнительном аспекте: в Германии - порядок, достаток, но в России свободнее, душевнее и пр.

«Я Россию люблю, я люблю туда ездить. Но жить мне комфортнее в Германии... <..> Я знаю систему, я знаю язык, я все знаю, как что где работает. Мне на данный момент было бы в России очень сложно интегрироваться. Хотя если кто-то, не дай Бог, плохо про Россию что-нибудь скажет, мне так больно и так обидно, что чувствуется все равно какой-то патриотизм. Но если кто-то бы меня спросил: "Хочешь ли вернуться в Россию жить?”, я бы, наверное, не захотела» (Ж., 31 год. Россия).

«На сегодняшний день все правильнее, комфортнее выстроено в Германии. <..> больше предсказуемости. И с практической точки зрения, конечно, в Германии жить удобно» (Ж., 58 лет. Казахстан).

«Мне нравится, я в Россию приезжаю, и я отдыхаю. Вот я захотел - поехал, порыбачил. Почему я разрешение какое-то должен делать в прорубь, где там столько рыбы специиально выкормили? < .. > Где захотел - остановился, куда захотел - отдыхать поехал» (М., 33 года. Россия).

Одним из молодых респондентов, назвавшим своей родиной Россию, было высказано желание вернуться обратно или, оставаясь в Германии, служить ее благу. «Хотелось бы, чтобы на самом деле мои дети жили в развиваюшейся России, чтобы я вернулся к корням истинным. Это у меня на самом деле есть. Но я не могу сказать, что у моей жены такие же мысли... <..> Но у меня есть. Чисто у меня есть такое, такая потребность и внутренний двигатель даже» (М., 32 года. Россия).

Можно предположить, что такая позиция характерна для определенной, пусть и небольшой части молодого поколения немцев-переселенцев (сам респондент отметил, что таких как он, мало: «Думаю, 90\% русских немцев ответили бы на вопросы иначе»). В двойственности их культурной идентичности можно усмотреть социальный потенциал, возможность создания коммуникативных сетей в России и Германии, успешного развития российско-германских экономических, политических, культурных связей. Цитируемый выше молодой человек на момент интервью, исходя из своей позиции, сознательно сменил профессию инженера на работу менеджера в международной компании, работающей на пространстве СНГ: «Вот мне хочется или хотелось бы какой-то вклад сделать в России. Хоть минимально, но хотелось бы что-то сделать. Если я здесь сижу и работаю по профессии на государство немецкое - это хорошо, и реализоваться можно, тоже не вопрос. Но мне хотелось бы сделать какой-то вклад...» (М., 32 года. Россия).

Отвечая на вопросы анкеты 2018 г., респонденты ярко и образно сформулировали понятие «Родина» и эмоционально высказали свое отношение к России. Судя по текстам, это напрямую обусловлено событиями 2014 г., связанными с осложнением внешнеполитических отношений между странами Запада и Россией в связи с включением с ее состав Крыма, непризнанием этих действий со стороны международного сообщества и, как следствие, введением международных санкций против РФ. 
«Россия (отвечу метафорой) - это тот мальчии$\kappa a$, который обычно сидит на задней парте. Он немного неопрятен, так как у его родителей временные трудности, и они не в состоянии создать ему опрятный вид. Те ребята, которые более зажиточные, и обычно являются любимчиками учителей, постоянно пытаются его унизить, собравшись в группу, так как поодиночке они трусливы. Тот парень спокоен, самодостаточен и неординарен. Он делает уроки, уважает учителей, относится к людям корректно. И как бы его не любили, все равно, странным образом, к нему испьтыввют глубокое уважение...» (М., 36 лет. Россия).

«Родина - это то место (или страна), куда постоянно влечет. Это то место, где твоей душе хорошо. Это место вызывает особое эмоциональное состояние. Такие чувства как сопереживание (в тяжелье времена) и радость (в более светлье времена) постоянно тебя сопровождают. Понятие "Родина" можно, в какой-то мере, сравнить с понятием “семья”. Это и родитель, который тебе дал жизнь и все необходимое для жизни. Но это и дитя, за которого волнуешься, переживаешь, безвозмездно любишь и гордишься за любые успехи» (Он же).

«Родина - Мать. Как можно забыть мать, родившую тебя... Даже если о ней не думаешь и не вспоминаешь до поры, до времени, пока у нее все хорошо. Но когда ее обижают или не справедливы к ней - сразу воспламеняется любовь. Поэтому враги России должны помнить, чем хуже они относятся к России (санкциии, русофобия в СМИ и т.д.), тем больше любви и патриотизма...» (Ж., 62 года. Казахстан).

Свою дальнейшую судьбу практически все из опрашиваемых связывают с Германией, обосновывая это тем, что эта страна является более благополучной в экономическом и правовом плане, в ней «правильнее», «комфортнее», «спокойнее» и др. Образ «исторической» Родины - России гораздо богаче: это и «семья», и «родитель», и «Мать», и «дитя». Международное давление в отношении России актуализировало в сознании респондентов чувства «волнения» и «сопереживания», «любви» и «патриотизма». Невозможность вернуться на родину компенсируется стремлением служить во благо России, оставаясь в Германии.

Bbыводы. Материалы исследования позволяют охарактеризовать представления русских немцев о родине в рамках исследуемой группы следующим образом. У респондентов четко прослеживается тенденция трансформации представлений об «исторической» родине. До эмиграции в качестве таковой воспринималась Германия, после - СССР и Россия. При довольно успешной экономической и социокультурной интеграции участников интервью в германское общество (обретение стабильных источников доходов приемлемого уровня, освоение законов и социальных механизмов, языка), на психологическом уровне полная интеграция в принимающее сообщество не состоялась. Респонденты четко отличают себя как от русских России, так и от коренных немцев, при этом данные отличия не имеет негативного или конфликтного характера. Скорее складывается концепция «двух родин», при этом собственное место в данной системе координат рассматривается, как некое посредничество.

Наблюдается явно различное отношение к этим «родинам». Германия, как «новая Родина», рассматривается как дом, место проживания, в котором есть такие положительные стороны, как социально-экономическая стабильность, гарантированное будущее себя и близких, безопасность, предсказуемость. «Старая» Родина (СССР и Россия) воспринимается как источник значимых личных смыслов и внутреннего психологического удовлетворения (культура и язык, связи с людьми, бытовая свобода, ностальгия, любовь и патриотизм). Формирование внутренних структур переселенческого сообщества трактуется русскими немцами как стремление воссоздать соответствующую этим смыслам микросреду, вписать образ «старой» Родины в новые жизненные реалии. У респондентов старшего поколения наблюдается чувство вины перед детьми за то, что они «лишили их Родины». У молодых респондентов в связи с этим не отмечается претензий к родителям, хотя присутствует осознание определенных затруднений с самоидентификацией, которые, по-видимому, не представляют собой большой проблемы и не мешают адаптации в принимающем сообществе.

В сознании большинства респондентов заметное место занимает тема ностальгии по утраченной родине (СССР, России). Объектами ностальгии являются оставшиеся в стране отъезда люди, «малая» родина, элементы образа жизни (интернациональные традиции, еда, личные памятные места). Не прослеживается ностальгия по странам и государствам: респонденты обобщенно определяют объект своей ностальгии как «Советский Союз» или «Россия», маркируя этими терминами определенный жизненный и культурный мир. Для всех респондентов важна тема сохранения связей со «старой» Родиной, характерно стремление передать русский язык и культуру детям, сохранить тесные связи с Россией, причем не только личные, но и деловые, профессиональные.

Анализ контекстов показал, что все многообразие выявленных признаков концепта «Родина» в изучаемой группе русских немцев может быть представлено в двух основных семантических профилях: «новая» Родина (Германия), как «дом» и место комфортного проживания, и «старая» / «историческая» Родина (СССР / Россия и Россия) как объект ностальгии и духовного притяжения.

Основой для формирования описанных выше представлений о родине послужил ряд факторов. Важным фактором являются причины эмиграции русских немцев. Во внешнем ракурсе эти причины связаны с распадом СССР, во внутреннем - с персональными социальными страхами (прежде всего за родных и близких), которые активизировались в связи с социаль- 
но-экономическим крахом прежней жизни. Некоторые респонденты указывают на отличие своих мотивов к эмиграции от мотивов переселенцев 1970-х гг.: если теми двигало желание переселиться в родную культурную среду, то отъезжающими в 1990-е гг. - стремление защититься от социальной катастрофы и обрести будущее для своих детей. У респондентов не было мотивации (или была, но слабо выраженная) к полной ассимиляции в Германии, как для себя, так и для детей и внуков. Соответственно, они не предпринимали сознательных усилий в этом направлении и не считали нужным избавляться от существующего языкового и культурного багажа.

Особое значение, как фактор формирования представлений о родине, имеет место отъезда - страна прежнего проживания. Респонденты уезжали из постсоветских республик, ставших новыми независимыми государствами. Эти государства не воспринимались ими как родина; то, что воспринималось в этом качестве - СССР, перестало существовать. Именно поэтому респонденты не демонстрируют государственного вектора своей ностальгии; она связывается с людьми, «малой» родиной, образом жизни, традициями, элементами культуры и быта СССР и / или русского мира («России») в целом. Особенно это характерно для выходцев из Казахстана и Киргизии.

Тесно связаны с формированием образа Родины этническая идентичность и возраст респондентов. Русские по этническому происхождению респонденты в качестве Родины назвали Россию (являющуюся и местом их рождения), респонденты, имеющие только немецкие корни или смешанное происхождение, в большинстве случаев заявляют о «двух» Родинах. Среди представителей старшего поколения более выражена ностальгия по СССР. Можно констатировать взаи- мообусловленность процессов формирования идентичности русских немцев и их представлений о Родине.

Важное место в формировании образа Родины имеют семейные установки в отношении страны исхода и принимающего государства и личный опыт интеграции русских немцев в принимающем сообществе. Практически все респонденты заявили об активном стремлении сохранить русский язык, культуру и связи с Россией для себя и своих детей и внуков, о роли семьи в практике этого сохранения. Такая позиция препятствует утрате «старой» идентичности и полной ассимиляции и постоянно актуализирует представления о «старой» Родине. Достаточно успешный опыт интеграции респондентов и благополучные условия проживания в принимающей стране позволил сформировать позитивный образ «новой» Родины.

Актуализация размышлений о «старой» и «новой» Родинах происходит и под воздействием международных событий, в эпицентре которых оказываются страны исхода и проживания переселенцев, примером чего может служить обострение в 2014 г. отношений между странами Запада и России в связи с включением в ее состав Крыма.

Развитие коммуникативной среды и открытые государственные границы позволяют сохранять в полном объеме личные связи с людьми, оставшимися в странах исхода, а развитие Интернета (в частности, инструменты социальных сетей) - и восстанавливать их. Переезд в другую страну перестал быть фактором «социальной смерти» для отъезжающих. Открытые границы, возможность путешествовать на историческую родину и самим принимать гостей оттуда также способствуют сохранению представлений о стране отъезда как о родной, развитию транснациональных связей и формированию позитивной транснациональной идентичности.

\section{ПРИМЕЧАНИЕ}

1 Здесь и далее по тексту цитируются материалы полевых исследований автора, собранные в 2014 г. в г. ФиллингенШвеннинген (Баден-Вюртемберг, ФРГ) [22]. Использование материалов полуструктурированного анкетирования, осуществленного в 2018 г., оговаривается в тексте специально указанием года [23].

\section{ЛИТЕРАТУРА}

1. (Spät-)Aussiedler und ihre Angehörigen. Zeitreihe 1950-2016. Herkunftsstaaten. Bundesverwaltungsamt BRD. URL: http://www.bva.bund.de/SharedDocs/Downloads/DE/BVA/Staatsangehörigkeit/Aussiedler/Statistik/Zeitreihe_1950_2016.pdf?_blob=publicationFil e\&v=3 (accessed: 24 July 2018).

2. Registrierung / Verteilung - seit dem Jahr 2001 nach Monaten und im Vergleich. Bundesverwaltungsamt BRD. URL: https://www.bva.bund.de/DE/Organisation/Abteilungen/Abteilung_BT/Spaetaussiedler/statistik/Monat/2a.html?nn=4487534 (accessed: 24 July 2018).

3. Spätaussiedler und ihre Angehörigen. Monatsstatistik September 2017. Bundesverwaltungsamt BRD. URL: http://www.bva.bund.de/SharedDocs/Downloads/DE/BVA/Staatsangehörigkeit/Aussiedler/Statistik/09_17_Monatsstatistik.pdf?_ blob=publicationF ile \&v=2 (accessed: 24 July 2018).

4. Бадалова Е.В. Институциональные условия интеграции российских немцев в Германии // Германия на перекрестках истории проблемы внутренней и внешней политики в контексте трансформаций международных отношений : сб. ст. / под общ. ред. А.А. Слинько ; отв. ред. С.И. Дмитриева. Воронеж, 2016. С. 97-104.

5. Самсонова Л.О. «Землячество немцев из России» и его деятельность в современной Германии // Вестник Адыгейского государственного университета. Сер. 1: Регионоведение: философия, история, социология, юриспруденция, политология, культурология. 2016. № 1 (174). С. 55-59.

6. Казарцева Е.В. Стратегии аккультурации русскоязычной молодежи Берлина // Журнал социологии и социальной антропологии. 2009. Т. ХІІ, № 4. С. $122-135$.

7. Стерликов В. Выявление проблем интеграции и адаптации подростков и молодежи из семей русскоязычных переселенцев в Германии // Омский научный вестник. 2007. № 2 (54). С. 62-67. 
8. Менг К., Протасова Е.Ю. Трансформация культурно-языкового самосознания российских немцев в Германии // Этнографическое обозрение. 2015. № 6. С. 13-25.

9. Попков В.Д. Покидая пределы этничности. Постсоветская эмиграция в Германии. Франкфурт-на-Майне : Посев, 2016.483 с.

10. Попков В.Д. «Культурная память» русскоязычных мигрантов в Германии: влияние на формирование новых идентичностей выходцев из бывшего СССР // Журнал социологии и социальной антропологии. 2013. T. XVI, № 1 (66). С. 148-166.

11. Иванова-Бучатская Ю. В. Российские немцы в Германии: знаковые объекты повседневной жизни и идентичность // Диаспоры. 2010 . № 2. С. $137-166$.

12. Глущенко Г.И. Транснационализм мигрантов и перспективы глобального развития // Мировая экономика и международные отношения. 2005. № 12. С. 50-57.

13. Филиппова Е.И. Дискурс об интеграции - консервативный анахронизм эпохи транснационализма // Транснациональные миграции и современные государства в условиях экономической турбулентности. М. : Дело, 2016. С. 305-322.

14. Савоскул. М.С. Трансграничные связи этнических мигрантов (на примере российских немцев в Германии) // Вестник Московского университета. Сер. 5. География. 2010. № 1. С. 78-83.

15. Савоскул М.С. Формирование и эволюция российско-германской транснациональной миграционной системы : автореф. дис. ... д-ра географ. наук. М., 2016. 46 с.

16. Савоскул М.С. Российские немцы в Германии: интеграция и типы этнической самоидентификации (по итогам исследования российских немцев в регионе Нюрнберг - Эрланген) // Демоскоп Weekly. 2006. № 243-244. URL: http://www.demoscope.ru/weekly/ 2006/0243/analit03.php (дата обращения: 24.08.2018).

17. Далгат Ф. М. К вопросу о концепции и методах антропологии в историческом исследовании // Евразийский союз ученых. 2014 . № 8-4. С. $91-94$.

18. Гусева И.И. Микроракурсы социального и стратегии их исследования // Известия Саратовского университета. Новая серия. Сер. Философия. Психология. Педагогика. 2014. Т. 14, № 2-1. С. 15-20.

19. Побережников И.В. Микроистория: действия и структуры в историческом контексте // Уральский исторический вестник. 2010. № 4 (29). C. $8-13$.

20. Приборович А.А. Дискурс-анализ как метод выявления факта из исторического источника // Веснік БДУ. Сер. 3. Гісторыя. Эканоміка. Права. 2012. № 2. С. 38-42.

21. Самсонова Л.О. Российские немцы: трудный путь возвращения на историческую родину (1990-2000-е гг.) // Голос минувшего. Кубанский исторический журнал. 2016. Т. 3-4, № 3-4. С. 154-158.

22. Полевые материалы автора (г. Филлинген-Швеннинген, земля Баден-Вюртемберг, Федеративная Республика Германия, ноябрь 2014 г.) // Личный архив Г.В. Грошевой.

23. Материалы дистанционного полуструктурированного анкетирования, ноябрь 2018 // Личный архив Г.В. Грошевой.

24. Казарцева Е.В. Роль культурной трансмиссии в процессе интеграции русскоязычной молодежи Германии // Актуальные проблемы гуманитарных и естественных наук. 2010. № 12. С. 391-395.

25. Gesetz über die Angelegenheiten der Vertriebenen und Flüchtlinge (Bundesvertriebenengesetz - BVFG). § 94 Familiennamen und Vornamen. URL: http://www.gesetze-im-internet.de/bvfg/_ 94.html (accessed: 2 October 2018).

26. Staatsangehörigkeitsgesetz (StAG). URL: http://www.gesetze-im-internet.de/stag/StAG.pdf (accessed: 2 October 2018)

27. Gesetz über die Angelegenheiten der Vertriebenen und Flüchtlinge (Bundesvertriebenengesetz - BVFG). § 94 Familiennamen und Vornamen. URL: http://www.gesetze-im-internet.de/bvfg/_94.html (accessed: 2 October 2018).

Galina V. Grosheva. Tomsk State Pedagogical University, Tomsk State University (Tomsk, Russia). E-mail: groshevagv@mail.ru BETWEEN “THE OLD” AND “THE NEW" MOTHERLAND: PERCEPTIONS OF RUSSIAN-GERMANS IN GERMANY

Keywords: motherland, identity, late resettlers, Russian-Germans, Germany.

The paper investigates the concept of motherland and aspects which form that vision of the Russian-speaking Germans, i.e. late resettlers (Spätaussiedler), who came to Germany from the former USSR countries (Russia, Kazakhstan, Kyrgyzstan) in 1990s.

Analysis of Russian historiography devoted to the issues of Russian-speaking Germans' emigration to Germany, integration of emigrants into German society, transformation of their self-consciousness, the experience of re-emigration (M.S. Savoskul, E.V. Kazartseva, I.V. Lebedev, M.A. Efremov, V.D. Popkov, etc.) confirms insufficiency of special works devoted to the issues of transformation of the motherland concept within the conscious of German resettlers.

The problem which is raised in the study is considered within trans-nationalism methodology which enables not to analyze the migration phenomenon in terms of national state and to consider emigrants as those possessing two and more identities. Micro-historical approach is used in the study which is centered on the definite person, his or her inner world and social practices. The method of linguistic discourse-analysis is used as additional one and it allowed tracing the respondents' directive towards the motherland concept on a verbal level.

The study is based on the empirical material (semi-structured in-depth group and individual interviews, overt observation) collected in Villingen-Schwenningen (Baden-Württemberg, Germany) in 2014. The data from questionnaire conducted in 2018 was used as supplementary materials.

The paper analyses several plots: the reasons for moving to Germany and discussions on the loss of "the old" motherland, the concept of motherland within the context of home-sickness on USSR and the country of origin, the problem of identity and the role of perceptions of Russia while formation of that identity, the concept of motherland considering integration and social adaptation problems, attitude of respondents to modern Russia and Germany.

The concludes. The respondents of the group under study are marked by the tendency for transformation of the perception of "historical" motherland. Prior to emigration they considered Germany as historical motherland, since then - USSR and Russia. At the same time the concept of "two motherlands" is developed. Germany, being "the new" motherland is entitled with such characteristics as social and economic stability, legal safeguards, predictability. "The old" motherland is accepted as the source of significant individual senses and inner psychological satisfaction. The factors for establishing the visions described above are the reasons for emigration and the former country of living, ethnic origin and the age of respondents, family policy towards the country of origin and host country, personal experience of integration, development of communicative environment and open state boundaries, foreign-policy developments.

\section{REFERENCES}

1. Federal Office of Administration Germany. (n.d.) (Spät-)Aussiedler und ihre Angehörigen. Zeitreihe 1950 - 2016. Herkunftsstaaten. [Online] Available from: http://www.bva.bund.de/SharedDocs/Downloads/DE/BVA/Staatsangehörigkeit/Aussiedler/Statistik/Zeitreihe_1950_2016.pdf?_blob= publicationFile\&v=3. (Accessed: 24th July 2018). 
2. Federal Office of Administration Germany. (n.d.) Registrierung / Verteilung- seit dem Jahr 2001 nach Monaten und im Vergleich. [Online] Available from: https://www.bva.bund.de/DE/Organisation/Abteilungen/Abteilung_BT/Spaetaussiedler/statistik/Monat/2a.html?nn=4487534. (Accessed: 24th July 2018).

3. Federal Office of Administration Germany. (2017) Spätaussiedler und ihre Angehörigen. Monatsstatistik September 2017. [Online] Available from: http://www.bva.bund.de/SharedDocs/Downloads/DE/BVA/Staatsangehörigkeit/Aussiedler/Statistik/09_17_Monatsstatistik.pdf?_blob=publicationF ile\&v=2. (Accessed: 24th July 2018).

4. Badalova, E.V. (2016) Institutsional'nye usloviya integratsii rossiyskikh nemtsev v Germanii [The institutional framework of integration of Russian Germans in Germany]. In: Slinko, A.A. \& Dmitrieva, S.I. (eds) Germaniya na perekrestkakh istorii: problemy vnutrenney $i$ vneshney politiki $v$ kontekste transformatsiy mezhdunarodnykh otnosheniy [Germany at the crossroads of history: problems of internal and foreign policy in the context of transformed international relations]. Voronezh: Voronezh State University. pp. 97-104.

5. Samsonova, L.O. (2016) "Association of Germans from Russia” and its activity in modern Germany. Vestnik Adygeyskogo gosudarstvennogo universiteta. Seriya 1: Regionovedenie: filosofiya, istoriya, sotsiologiya, yurisprudentsiya, politologiya, kul'turologiya - Bulletin of the Adygeya State University. Region Studies: Philosophy, History, Sociology, Jurisprudence, Political Sciences, Culturology. 1(174). pp. 55-59. (In Russian).

6. Kazartseva, E.V. (2009) Strategii akkul'turatsii russkoyazychnoy molodezhi Berlina [Acculturation strategies of Russian-speaking young people in Berlin]. Zhurnal sotsiologii i sotsial'noy antropologii - Journal of Sociology and Social Anthropology. 4. pp. $122-135$.

7. Sterlikov, V. (2007) Vyyavlenie problem integratsii i adaptatsii podrostkov i molodezhi iz semey russkoyazychnykh pereselentsev v Germanii [Identification of the problems of integration and adaptation of adolescents and young people from Russian-speaking immigrant families in Germany]. Omskiy nauchnyy vestnik-Omsk Scientific Bulletin. 2(54). pp. 62-67.

8. Meng, K. \& Protassova, E.Yu. (2015) The Transformation of Cultural-Linguistic Identity of Russian Germans in Germany. Etnograficheskoe obozrenie-Ethnographic Review. 6. pp. 13-25. (In Russian).

9. Popkov, V.D. (2016) Pokidaya predely etnichnosti. Postsovetskaya emigratsiya v Germanii [Beyond the boundaries of ethnicity. Post-soviet emigration in Germany]. Frankfurt on Main: Posev.

10. Popkov, V.D. (2013) "Kul'turnaya pamyat" russkoyazychnykh migrantov v Germanii: vliyanie na formirovanie novykh identichnostey vykhodtsev iz byvshego SSSR [The "cultural memory" of Russian-speaking migrants in Germany: Impact on the formation of new identities of immigrants from the former Soviet Union]. Zhurnal sotsiologii i sotsial'noy antropologii-Journal of Sociology and Social Anthropology. 1(66). pp. 148-166.

11. Ivanova-Buchatskaya, Yu.V. (2010) Rossiyskie nemtsy v Germanii: znakovye ob"ekty povsednevnoy zhizni i identichnost' [Russian Germans in Germany: Symbolic objects of everyday life and identity]. Diaspory. 2. pp. 137-166.

12. Glushchenko, G.I. (2005) Transnatsionalizm migrantov i perspektivy global'nogo razvitiya [Migrant transnationalism and prospects of global development]. Mirovaya ekonomika i mezhdunarodnye otnosheniya - World Economics and International Relations. 12. pp. 50-57.

13. Filippova, E.I. (2016) Diskurs ob integratsii - konservativnyy anakhronizm epokhi transnatsionalizma [Discourse on integration as a conservative anachronism of the era of transnationalism]. In: Malakhov, V. \& Simon, V. (eds) Transnatsional'nye migratsii i sovremennye gosudarstva v usloviyakh ekonomicheskoy turbulentnosti [Transnational Migrations, Contemporary States, and Economic Turbulence]. Moscow: Delo. pp. $305-322$.

14. Savoskul, M.S. (2010) Transgranichnye svyazi etnicheskikh migrantov (na primere rossiyskikh nemtsev v Germanii) [Trans-border relationships of ethnic migrants (a case study of Russian Germans in Germany)]. Vestnik Moskovskogo universiteta. Seriya 5. Geografiya - Moscow University Bulletin. Series 5, Geography. 1. pp. 78-83.

15. Savoskul, M.S. (2016) Formirovanie i evolyutsiya rossiysko-germanskoy transnatsional'noy migratsionnoy sistemy [The Formation and evolution of the Russian-German transnational migration system]. Abstract of Geography Dr. Diss. Moscow.

16. Savoskul, M.S. (2006) Rossiyskie nemtsy v Germanii: integratsiya i tipy etnicheskoy samoidentifikatsii (po itogam issledovaniya rossiyskikh nemtsev v regione Nyurnberg - Erlangen) [Russian Germans in Germany: integration and types of ethnic identity (a case study of Russian Germans in Nürnberg - Erlangen)]. Demoskop Weekly. 243-244. [Online] Available from: http://www.demoscope.ru/weekly/2006/0243/analit03.php. (Accessed: 24th August 2018).

17. Dalgat, F.M. (2014) K voprosu o kontseptsii i metodakh antropologii v istoricheskom issledovanii [On the concept and anthropology methods in historical study]. Evraziyskiy soyuz uchenykh. 8-4. pp. 91-94.

18. Guseva, I.I. (2014) Mikrorakursy sotsial'nogo i strategii ikh issledovaniya [Social aspects and their research strategies]. Izvestiya Saratovskogo universiteta. Novaya seriya. Seriya: Filosofiya. Psikhologiya. Pedagogika-Izvestiya of Saratov University. New Series. Series: Philosophy. Psychology. Pedagogy. 14(2-1). pp. 15-20.

19. Poberezhnikov, I.V. (2010) Mikroistoriya: deystviya i struktury v istoricheskom kontekste [Micro-history: actions and structures in historical context]. Ural'skiy istoricheskiy vestnik - Ural Historical Journal. 4(29). pp. 8-13.

20. Priborovich, A.A. (2012) Diskurs-analiz kak metod vyyavleniya fakta iz istoricheskogo istochnika [Discourse analysis as a method of revealing a fact from a historical source]. Vesnik BDU. Seryya 3, Gistoryya. Ekanomika. Prava. 2. pp. 38-42.

21. Samsonova, L.O. (2016) Rossiyskie nemtsy: trudnyy put' vozvrashcheniya na istoricheskuyu rodinu (1990-2000-e gg.) [The Russian Germans: a difficult path of returning to their historical homeland (1990-2000s)]. Golos minuvshego. Kubanskiy istoricheskiy zhurnal. 3-4. pp. 154-158.

22. Grosheva, G.V. (2014) Polevye materialy avtora (g. Fillingen-Shvenningen, zemlya Baden-Vyurtemberg, Federativnaya Respublika Germaniya, noyabr' 2014 g.) [Field materials of the author (Villingen-Schwenningen, Baden-württemberg, Germany, November 2014)]. Personal archive of the author.

23. Grosheva, G.V. (2018) Materialy distantsionnogo polustrukturirovannogo anketirovaniya, noyabr' 2018 [Remote semi-structured survey materials, November 2018]. Personal archive of the author.

24. Kazartseva, E.V. (2010) Rol' kul'turnoy transmissii v protsesse integratsii russkoyazychnoy molodezhi Germanii [The role of cultural transmission in the process of integration of Russian-speaking young people in Germany]. Aktual'nye problemy gumanitarnykh i estestvennykh nauk. 12. pp. 391395 .

25. Bundesvertriebenengesetz - BVFG. (n.d.) Gesetz über die Angelegenheiten der Vertriebenen und Flüchtlinge (Bundesvertriebenengesetz - BVFG). $\S 94$. Familiennamen und Vornamen. [Online] Available from: http://www.gesetze-im-internet.de/bvfg/_94.html. (Accessed: 2nd October 2018).

26. Staatsangehörigkeitsgesetz (StAG). [Online] Available from: http://www.gesetze-im-internet.de/stag/StAG.pdf. (Accessed: 2nd October 2018).

27. Bundesvertriebenengesetz - BVFG. (n.d.) Gesetz über die Angelegenheiten der Vertriebenen und Flüchtlinge (Bundesvertriebenengesetz - BVFG). $\S 94$. Familiennamen und Vornamen. [Online] Available from: http://www.gesetze-im-internet.de/bvfg/_94.html. (Accessed: 2nd October 2018). 